\title{
CZECH SWAP MARKET IN THE CRISIS PERIOD
}

\author{
Martin Pohl*
}

\begin{abstract}
:
The swap market is key segment of the fixed income market due to its liquidity and tight links to other market segments. In our paper we estimate basic parameters of the swap curve and we test the stability of these parameters during the crises period. Our estimate confirms that the Czech swap curve may be represented by three components that track its level, slope and curvature. These parameters were stable during the crises period that culminated in the autumn 2008. On contrary, the basic swap curve characteristics are showing most abnormal behaviour during periods of relative calm development. The traditional determinants of the Czech swap curve remain monetary policy, euro swap rates and risk premiums. Although risk premiums are low in the swap market, the large increase in risk premium in the Czech money market rates had significant impact on the swap curve slope during the crises period.
\end{abstract}

Keywords: financial crises; multivariate methods; swap curve; money market

JEL Classification: C38, G01

\section{Introduction}

Our aim is to analyze the Czech swap market development during years 2008 and 2009, when the global financial system was hit by a financial crisis. We focus on three issues. Firstly, we try to confirm the basic assumptions on yield curve behaviour. The yield curve is usually represented by its three basic parameters - level, slope and curvature, but financial crises may have altered the traditional yield curve dynamic. Secondly, we are interested in the development of bid/ask spreads during the crises period. Thirdly, we analyze the development of key determinants of the Czech swap curve - monetary policy rates, euro swap curve and risk premiums. We put special attention to money market, because it is the key to understand some "anomalies" in the development of the swap market in the years 2008 and 2009.

There is a large body of literature that deals separately with swap and more often bond market dynamics or with 2008/2009 financial crisis. Financial crisis was followed by many researchers, international institutions and central banks. Probably the most convincing explanation was offered by Gordon (2009) who interpreted the 2008/2009

* University of Economics Prague (VŠE), Banking and Insurance Department, W. Churchill Sq. 4, 13067 Prague, Czech Republic (pmartin@centrum.cz).

The paper is processed as an output of a research project founded by the Internal Grant Agency of University of Economics, Prague (project number 24/2010). 
financial crisis as a modern form of classic bank run. The bank run severely impacted interbanking markets of which interest rate swaps are important part. We advise readers to turn attention to IMF (2008) for international overview and to CNB (2009 and 2010) for overview of the Czech financial market development. We think that our approach is novel in our focus on Czech swap markets during the crisis period.

Swap markets are key part of fixed income markets, although less followed in the literature. A comprehensive overview of advanced interest rate models may be found in Málek (2005). Practical applications on Czech government bond markets were offered by Kladívko (2010), Málek (2007) and Slavík (2001) where authors use Nelson-Siegel class models to estimate yield curve. In contrast to them, we use nonparametric primary component analysis (PCA) and we do not estimate zero bond curve, but purely describe swap curve dynamic. Different application of primary component analysis may be found in Cícha (2010) who models key primary components by using nonlinear stochastic differential equations. Papers dealing with interest rate swap are relatively rare in the Czech context. Notable exception is Witzany (2009) with his study on valuation of convexity related interest rate derivates.

\section{Theoretical Concepts}

\subsection{Term structure theories}

The classical theories (see Martellini, 2003) of the term structure are the pure expectation theory, pure risk premium theories and the market segmentation theory. The biased expectation theory combines the pure expectation theory and pure risk premium theory. It splits long-term interest rates into the expected path of short-term interest rates and risk premiums. We think that this approach is especially relevant in the context of our paper due its emphasis on different sources of interest rate dynamic.

The expected path of short-term interest rates may be interpreted in terms of expected path of economic fundamentals in Taylor like functions (see Clarida, 2001). Sharp swings of interest rates during the crisis period were indeed accompanied with abruptly changing economic environment and expectations for future growth and inflation that are reflected mainly in yield curve slope. If the market expects the economic situation to worsen, the expected short-term interest rate is going down. The yield curve will flatten or may even get inverse. If the market expects on contrary an economic recovery, the yield curve will be relatively steep implying rising short term interest rates.

The risk premiums in the fixed income markets may be decomposed into three components - term, credit and liquidity premium. Term premium reflects the fact that holding an asset with longer maturity is more risky than asset with lower maturity. The term premium is usually positive and increasing with the maturity of the fixed income instruments. It is one of the main reasons why we usually observe a rising yield curve. Credit premium reflects the risk that lender's claim may be not honoured in full. Credit premiums become especially relevant during the period of market stress and economic downturn and we will show later that they impacted also the Czech swap markets. 
Liquidity premium should be higher for low liquidity instruments and may be expected to increase during periods of market stress.

\subsection{Interest rate swaps}

The traditional yield curve concepts are connected to bonds markets, but they may be applied to swap markets as well. Nowadays both markets are tightly connected and interest rate swaps serve as close substitutes to "risk free" instruments like government bonds. In many markets (Euro, Czech) the swap markets are even more liquid than government bond markets. This enables to use swaps as a tool for duration management. Swaps also serve for debt conversion and they are used to create new assets that may even not exist in the markets. This makes interest rate swap markets one of the key segments of modern fixed income markets.

\subsubsection{Definition}

There are many different kinds of swaps, but plain vanilla interest rate swap has usually following characteristics (Martellini, 2003, p. 325):

- It has two legs - fixed leg whose payments depend on a fixed rate and a floating leg whose payments depend on a floating rate;

- Notional principal remains constant over the life of the contract;

- The maturity of the floating-rate is identical to the payment frequency of the floating-leg flows.

The interest rate swap is a derivate and it should have zero value at the beginning of the contract if we assume the bid/ask spread to be zero. In this context the swap rate is a rate, under which the current value of floating-leg flow equals to fixed-leg flows.

$$
\sum_{j=1}^{n} r^{*} \rho_{j}=\sum_{j=1}^{n} f r_{j-1, j} * \rho_{j}
$$

$$
\begin{array}{ll}
r & =\text { swap rate } \\
\rho_{j} & =\text { discount factor with maturity } \mathrm{j} \\
f r_{j-1, j} & =\text { one period forward rate }
\end{array}
$$

\subsubsection{Links to government bond market}

The discount factor and forward rate provide the key links to government bond markets. The discount factor is a nonlinear function of the $\mathrm{n}$-period interest rate that may be interpreted according to the biased expectation theory.

$$
\rho_{j}=\left(1+R_{t, j}\right)^{-j}
$$


The expectation theory also shows that the n-period interest rate may be decomposed into products of one period forward rates that are the base for the floating rate leg of the swap.

In reality is the connection between both markets more complicated, although it remains tight. The underlying interest rate in the swap market is a money market benchmark usually of a three or six month maturity. The liquidity and credit premiums in both markets are different and their time structure may be nontrivial. For this reasons is common to construct different yield curves for the interbanking (swap) market and for the government market.

\subsubsection{Risk premiums}

Basic risk premium decomposition into three parts (term, credit and liquidity premium) is useful also in the context of swap markets. Usually we observe a positive slope of the swap curve what is consistent with rising term premium.

The credit premium seems to be very low in the swap market for more reasons. Firstly, the credit risk of a banking sector is similar to the risk of the sovereign. The banking sector is heavily regulated industry and it assumed and confirmed by practice that there is an implicit option that at least large banks will be rescued rather than they will default. Secondly, the swaps are derivates. This means that a swap contract starts as zero investment for both parties. The risk is associated only with the real value of the contracts which reflects the profit/loss from the contract. This risk is further reduced by the margin system.

Although the credit risk associated with a swap contract remains relatively low, the credit premium may have a significant impact on swaps with short maturity. The reason is the underlying instrument of the floating leg - the money market rate. Money market rates are interest rates for unsecured loans in the interbanking markets. High credit risk in the banking sector may impact money market rates and this will impact also the swap curve. Ceteris paribus, higher risk premiums in the money market lead to a flatter swap curve.

The liquidity premium in the swap market seems to be relatively low. In most countries the swap market is more liquid than the government bond market and it is usually cheaper to trade swaps than bonds.

We may conclude that risk premiums in the swap markets are important, but they are mostly lower than for any other fixed income assets including government bonds. The swap rates may be used as risk free benchmark for valuation of other securities and also for accounting purposes in the financial industry. 


\section{Methodology}

A common approach to study the yield curve dynamic is to use well known multivariate methods like factor and principal component analysis (Dieudonne, 2004). In this paper we focus on the later. The basic idea of both approaches is to find hidden or latent variables that are called factors or primary components. The main advantage of this approach is the reduction of the multivariate sample to a few variables that represent a reasonable approximation of the sample. In the principal factor analysis we focus on the diagonal entries of the covariance matrix $\mathrm{C}$. The aim is to achieve a maximal reproduction of covariance matrix by the new variables. The new variables will also explain the maximum of the total variance. Principal component method is a nonparametric method and we do not need to impose restriction on distribution, dependence and heterogeneity of the variables in the sense that parametric methods do. On the other hand, we are aware that nonparametric methods usually impose hidden nontrivial restrictions that are difficult to follow.

The principal component method is scale dependent. Although interest rates are relatively homogenous set of variables, we use the orthodox approach and we normalize variables (swap rates) by removing the mean and dividing by its standard deviation.

$$
s_{i, j}^{n}=\frac{s_{i, j}-\operatorname{mean}\left(s_{j}\right)}{\operatorname{stddev}\left(s_{j}\right)}, i=1,2, \ldots T, j=1,2, \ldots, p
$$

The basis of the principal component analysis is the eigendecomposition of the matrix. The idea is that a square matrix may be represented by its eigenvalue $\lambda$, that will satisfy following equation.

$$
C^{*} x=\lambda * x
$$

The solution may be found by solving this equation system.

$$
\operatorname{det}(C-\lambda * I)=0
$$

In order to maximise the explained variance we take the first eigenvalue and eigenvector to derive the first component. The first principal component is than a linear combination of the first eigenvector $x_{1}$ and normalized swap rates $s^{n}$ :

$$
P C_{1}=x_{1}{ }^{*} s^{n}
$$

We always take the highest remaining eigenvalue and corresponding eigenvector. The eigenvectors are by definition orthonormal for symmetric matrices.

The eigendecomposition offers a simple tool, which enables us to make judgement on the relative importance of principal components. Following useful representation says that the trace of the covariance matrix is equal to the sum of its eigenvalues

$$
\operatorname{trace}(C)=\sum_{j=1}^{p} \lambda_{j}
$$


The relative importance of a component is than expressed as a quotient of its eigenvalue and of the trace of the matrix. We may also represent the covariance matrix in terms of its eigenvalues and eigenvectors. Following equation shows how well we replicate the covariance matrix by adding additional components.

$$
C=\sum_{j=1}^{p} \lambda_{j} * x_{j} * x_{j}{ }^{\prime}
$$

We found also useful the Mahalanobis (Hebák, 2005) distance of two multivariate distributions. The statistic measures the distance between means of two multivariate distributions, which are assumed to have the same covariance matrix. The measure respects different variability of variables and the correlation structure of the sample.

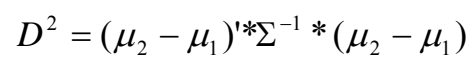

where $\mu_{i}$ is the sample mean and $\Sigma$ is the covariance matrix that is calculated as the weighted average of both covariance matrices.

\section{Data}

Our aim is to analyze the development of the Czech swap market during the years 2008 and 2009. For this purpose we use daily data. Our main data source for swap rates, money market rates and CDS rates is Bloomberg. The basic statistics of daily swap rates are in the Table 1. Swap rates are sorted in columns (s1-s10) where numbers indicated swap rate maturity.

Table 1

\section{Descriptive Statistics}

\begin{tabular}{|l|c|c|c|c|c|c|c|c|c|c|}
\hline Statistics & s1 & s2 & s3 & s4 & s5 & s6 & s7 & s8 & s9 & s10 \\
\hline Mean & 3.06 & 3.19 & 3.36 & 3.48 & 3.57 & 3.63 & 3.70 & 3.77 & 3.85 & 3.94 \\
\hline Median & 2.85 & 2.80 & 3.06 & 3.28 & 3.44 & 3.53 & 3.61 & 3.69 & 3.78 & 3.87 \\
\hline Max & 4.67 & 4.78 & 4.78 & 4.78 & 4.78 & 4.78 & 4.79 & 4.80 & 4.82 & 4.85 \\
\hline Min & 1.64 & 2.13 & 2.30 & 2.40 & 2.50 & 2.59 & 2.70 & 2.80 & 2.90 & 3.02 \\
\hline St. Dev. & 0.92 & 0.74 & 0.63 & 0.56 & 0.52 & 0.50 & 0.49 & 0.47 & 0.45 & 0.43 \\
\hline Skew. & 0.10 & 0.40 & 0.44 & 0.37 & 0.31 & 0.29 & 0.26 & 0.24 & 0.21 & 0.17 \\
\hline Kurtosis & -1.57 & -1.39 & -1.15 & -0.96 & -0.89 & -0.89 & -0.93 & -0.96 & -0.98 & -0.99 \\
\hline
\end{tabular}

Source: Author's estimates, Bloomberg

The swap curve was on average upward sloping and the long-term rates were more stable than short-term interest rates. Both findings are consistent with the expectation theory. The empirical distribution was slightly skewed towards higher values and it seemed to be platokurtic. We should not draw far reaching conclusions from these parameters as we used only a short period that was marked by a financial crises and interest rate reductions. 


\section{Swap Curve Basics}

The yield curve behaviour is usually described by three parameters - level, slope and curvature. Level and slope shifts are usually connected to economic development. Curvature seems to be dependent mostly on technical factors like financial crises, liquidity squeeze or flight to quality moves. Our estimate confirms that it has been also the case for the Czech swap curve. The component weights reflect the sensitivity of components to different maturity segments of the swap curve. We clearly see that the first component reflects parallel shifts of the yield curve, the second steepening/ flattening pressures and the third changing curvature.

Figure 1

\section{Component Weights}

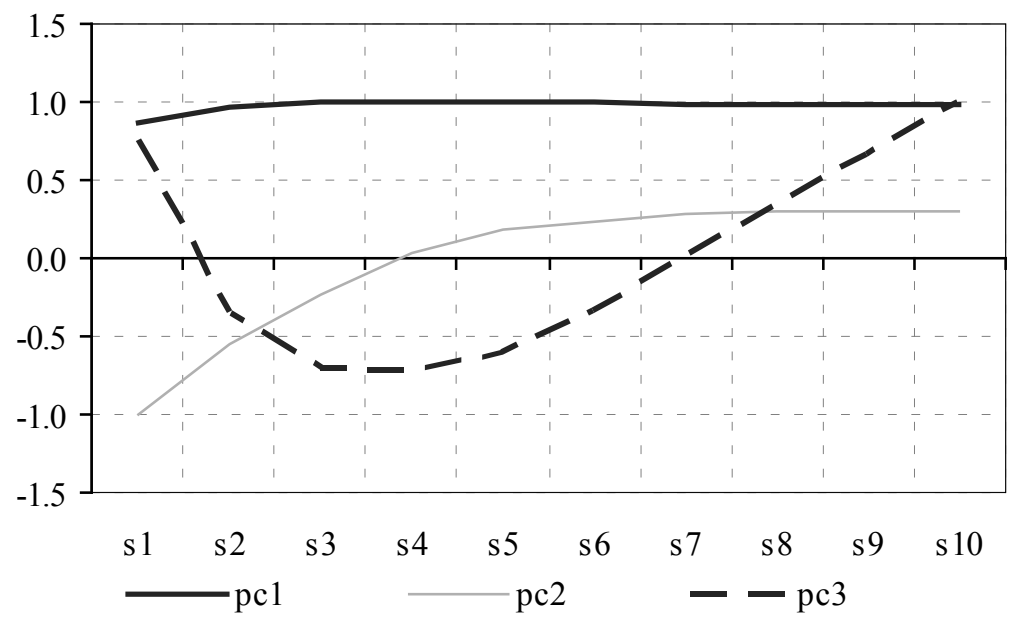

Source: Author's estimates

The explanatory power of all primary components is depicted in Figure 2. The first three components representing basic yield curve movements seem to be a sufficient representation of the Czech yield curve. Our estimate suggests that the first and second component explain together $99.7 \%$ of variability during sample period. The other components may be thus ignored as unimportant, but we return later to the third component for its interesting features. 
Figure 2

\section{Explanatory Power}

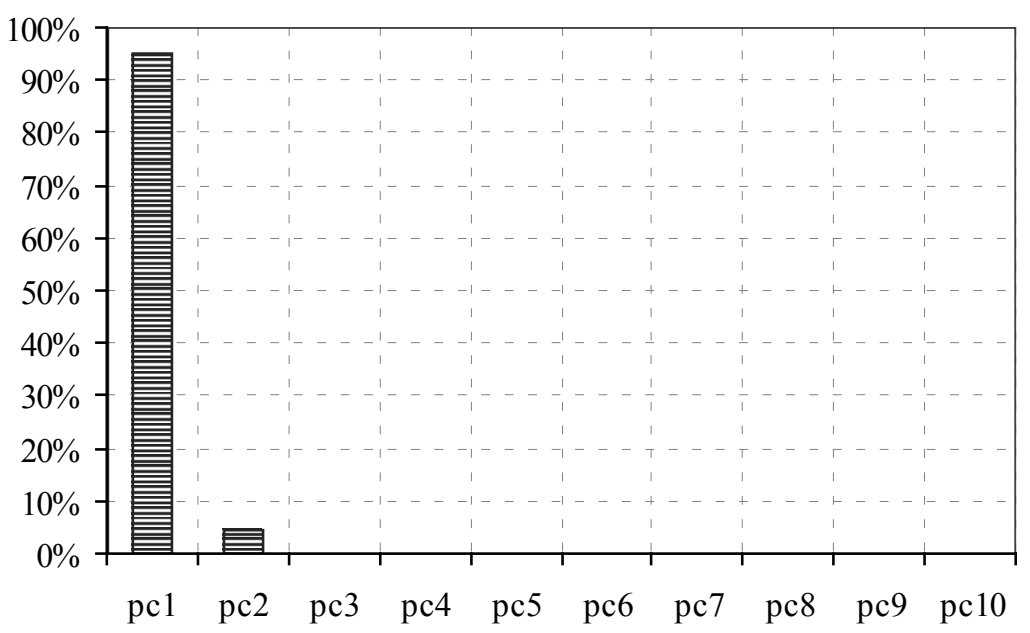

Source: Author's estimates

\section{The Crises Period}

The development of first and second component reflects the difficult period that the Czech financial system has been facing in 2008 and 2009. The beginning of the period was characterized by increasing pressures towards higher rates that were boosted by the rate hike of ECB in June 2008. This event had impact also on Czech swap rates due to its natural links to euro markets. We can see it in the Figure 3 as the spike of the first principal component around the middle of 2008. The Czech National Bank was sending signals in its forecasts that risks are skewed towards lower future interest rates and this helped to keep shorter swap maturities relatively lower. Curve steepening pressures and rising second component was a natural outcome.

The subsequent financial crisis was characterized by falling interest rates and a flatter yield curve as the outlook for the Czech and global economy darkened. The trend was interrupted by the post Lehman Brother meltdown. These events caused a disintegration of markets. There was a general mistrust among banks and even the Czech state had difficulties to find funding. The spread between the policy rate and $3 \mathrm{M}$ Pribor reached $150 \mathrm{bp}$ in November 2008. Pribor is the usual floating rate for Czech interest rate swaps and this development resulted in a brief period of rising swap rates and flatter curve. This is reflected in the spike of the first and second principal component in the autumn of 2008 . 


\section{Figure 3}

\section{First and Second Component}

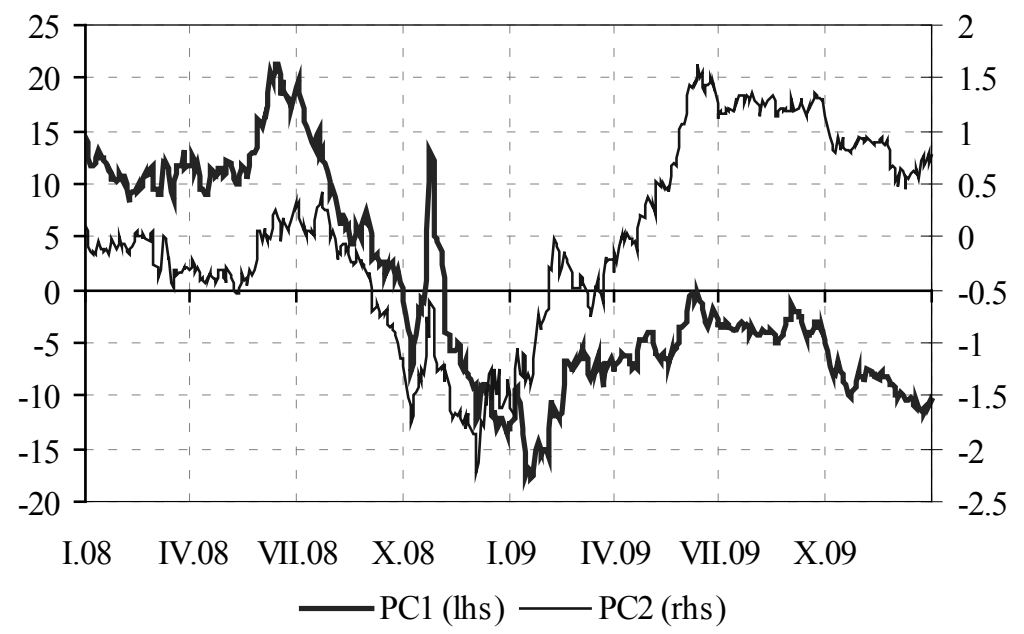

Source: Author's estimates

The near collapse of the banking sector forced authorities to provide stabilization measures that helped to calm down the situation. The Czech swap rates started to follow the lead of global interest rate markets and also declining domestic policy rate provided support for Czech fixed income markets. At the beginning of the year 2009 the rates reached the bottom and markets has started to get more optimistic on future prospects of the economy. Both components started to grow again in winter 2008/2009.

The recovery of the markets contributed to rising interest rates and the swap curve peaked during 3Q 2009. The Czech national bank continued to reduce its interest rates during 2009 to $1 \%$ in December 2009. This contributed together with declining premiums in the money markets to the steepening of the swap curve during 2009.

The decline of swap rates in 4Q 2009 reflected market's skeptical view on the recovery strength, declining policy rates (refinancing rate reached $1 \%$ ) and falling risk premiums and yields in the Czech government bond market. The last factor dominated and contributed to a more significant decline in intermediate and longer-term maturities what was mirrored in a decline of the second component and swap curve flattening.

Although the third component seems to have a mirror effect on the overall swap rates dynamic, we think that it is worth to look more closely on it. 
Figure 4

Third Component

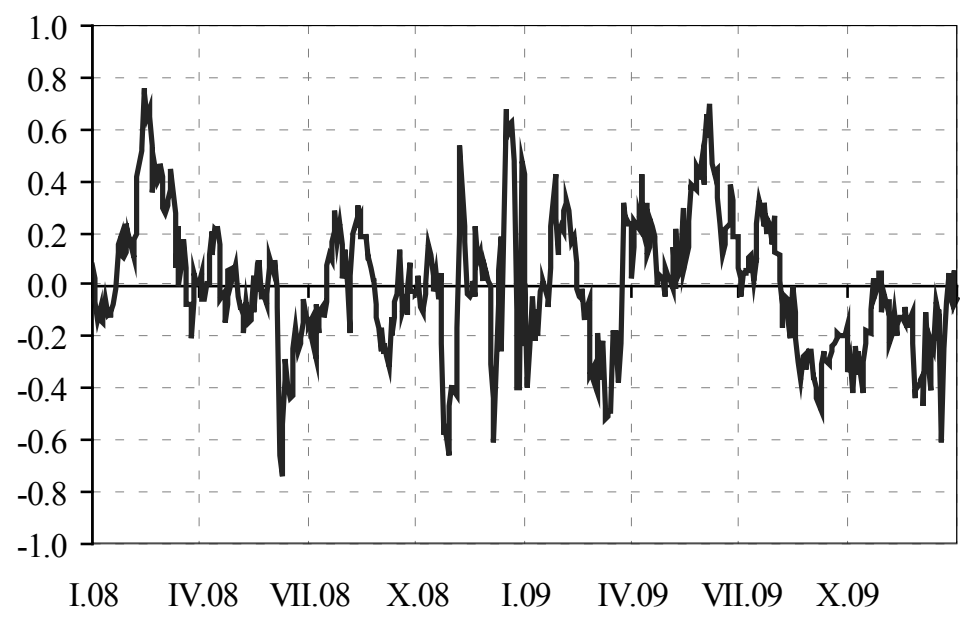

Source: Author's estimates

What is probably most puzzling, that there is nothing puzzling at all despite the turmoil and volatility of last two years. The third component seems to be "almost" stationary and there does not seem to be a break in 4Q 2008, although there is a cluster of higher volatility. The tendency to mean reversion of the curvature component is often used by investors. The basic logic of these trades is to open different position on the wings and in the belly of the yield curve to profit from the mean reversion process. Although our data inspection provides support for such trades in the Czech market, we would be cautious. The potential gains may be not big enough to offset the transaction costs in the Czech market. We see a back testing procedure as necessary to confirm this result.

\subsection{Quarterly data inspection}

Although the full sample supports "textbook" view on yield curve dynamic, the inspection of quarterly subsamples offers more ambitious picture. The explanatory power of main components varies significantly. The explanatory power declined to $80 \%$ in 2Q 2009 and in 3Q 2009. We think that this reflects mostly the lack of big macro stories or surprises. Our economy and financial markets recovered in line with their foreign counterparts. The level component stagnated during both quarters. In this situation other factors became more important. 
Figure 5

Explanatory Power Quarterly

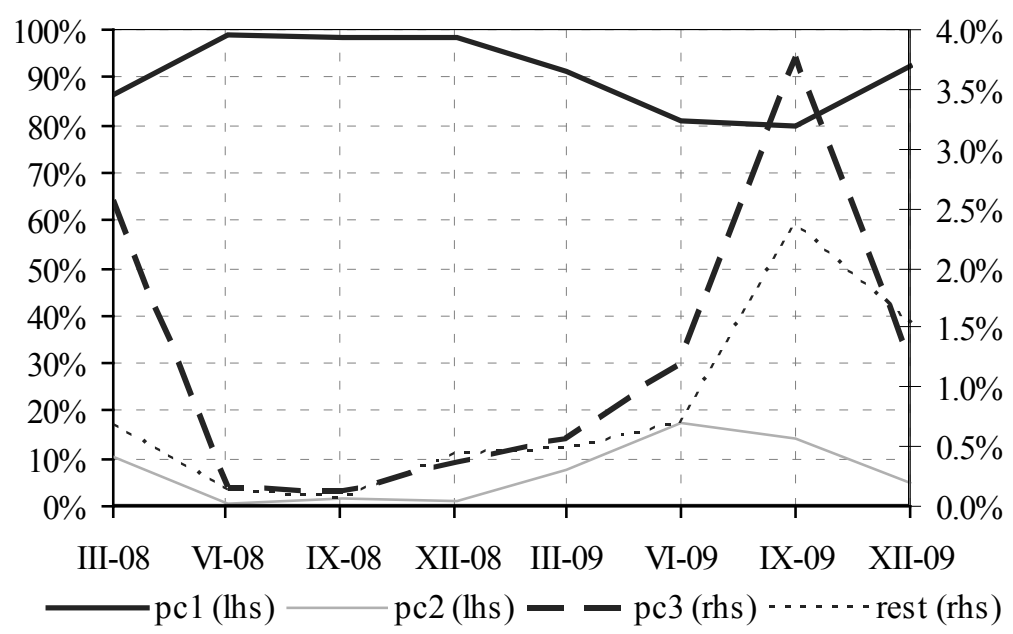

Source: Author's estimates

We took a look on the component weights that we estimated on quarterly data. The components weights were uniform across maturity spectrum, but they look "reverse U" shaped during the post-crisis period in 2Q 2009 and 3Q 2009, when there was no clear trend in the level of swap rates.

Figure 6

First Component Quarterly

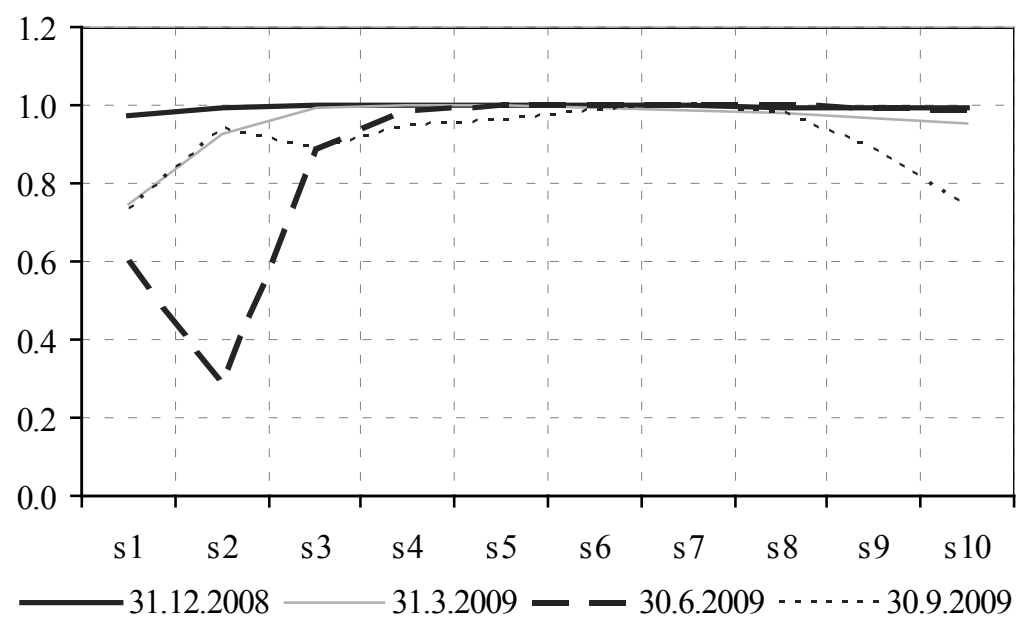

Source: Author's estimates 
The results are similar also for other two components. The components weights are stable for the crises period similar to full sample results. The most abnormal estimates were obtained again for the 3Q 2009, when the swap curve was remarkable stable in terms of level and slope.

\subsection{Bid/ask spreads during crises period}

Another interesting question concerns the spread that the "market makers" charge from opposite positions in the market. The spreads should naturally reflect their ability and willingness to carry positions on their books. We would expect the bid/ask spreads to widen in line with the general increase in risk premiums in the market. Of course we are aware that our data reflect only "indicative" quotations that may be different from rates actual terms of closed trades. We think that large differences may exist only for brief periods of time as swaps are viewed as the most liquid Czech fixed income market and our focus is rather on general trend during crises period.

The multivariate variance structure of bid/ask spreads is similar to the underlying curve. The graph shows that we may also identify components that describe level, steepness and curvature of the spread curve. There are few important differences. Firstly, the key components are less dominant for the total variance. The first component accounts for $74 \%$ of total variance, second for $8.2 \%$ and third for $4.5 \%$. Closer inspection of the data shows that this may be connected to lower quality of underlying data from Bloomberg. Secondly, the second and higher components are less "smooth". We see large jumps in components loading for $1 \mathrm{Y}$ maturity, $5 \mathrm{Y}$ and $10 \mathrm{Y}$ maturity. The "abnormal" behaviour of the $1 Y$ swap rate reflects its higher sensitivity on money market rates in comparison to longer maturities. The jumps for $5 \mathrm{Y}$ and $10 \mathrm{Y}$ maturity are mainly about higher liquidity of these maturities. They serve as swap equivalent for large benchmark issues in the bond markets.

Figure 7

\section{Component Structure of Bid/Ask Spreads}

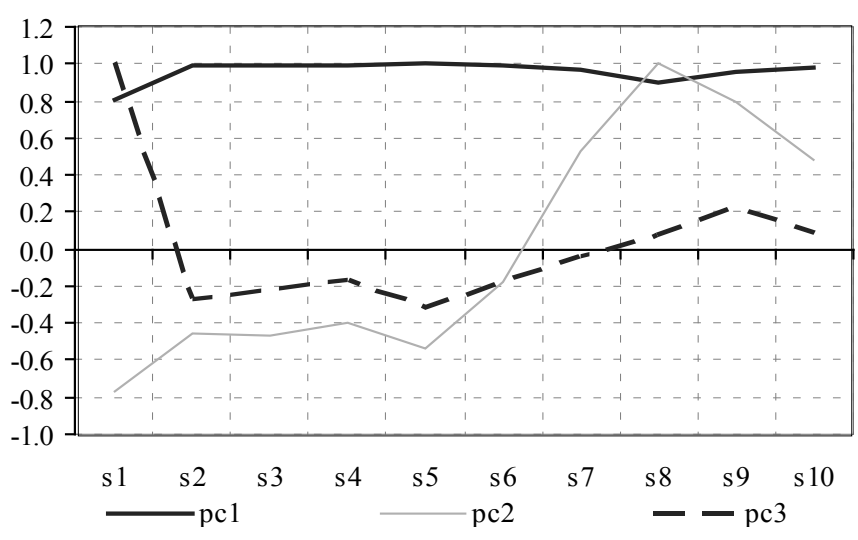

Source: Author's estimates 
We decided to use the Mahalanobis metric and average spread for all maturities to get some intuition about quarterly development of spreads. The following graph shows that spreads were relatively stable in 2008 even after at the high of financial crises. They started to widen in 2009 and reached the high in 3Q 2009 and than started again to decline.

Figure 8

Bid/Ask Quotation Distance

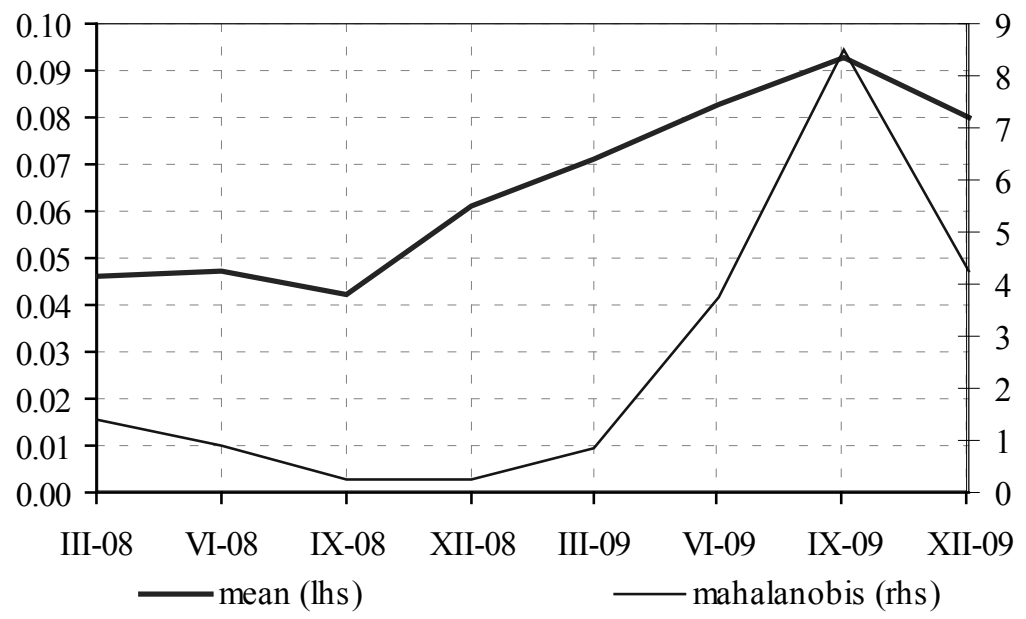

Source: Author's estimates

We may conclude that there was a long lag between the spreads and other variables during the crises period. We will return to this fact later.

\subsection{Liquidity of swap markets}

The decline of liquidity was a real problem for even most liquid markets and data confirm that the Czech swap market was no exemption. The Czech National Bank conducts a regular survey that measures liquidity in various segments of the interbanking market. The survey shows that there was a large drop in market activity during the survey week between October 6 and October 102008. 
Table 2

Swap Market Average Daily Turnovers in mil. CZK

\begin{tabular}{|l|c|c|c|c|c|c|}
\hline Period & $\mathbf{( 0 ; 1 Y >}$ & $\mathbf{( 1 Y ; 2 Y >}$ & $\mathbf{( 2 Y ; 5 Y >}$ & $\mathbf{( 5 Y ; 1 0 Y >}$ & $\mathbf{( 1 0 Y - )}$ & Total \\
\hline October 2009 & 812 & 1098 & 720 & 200 & 60 & 2890 \\
\hline July 2009 & 0 & 700 & 1356 & 628 & 74 & 2758 \\
\hline April 2009 & 300 & 100 & 726 & 898 & 140 & 2164 \\
\hline October 2008 & 0 & 200 & 80 & 400 & 20 & 700 \\
\hline April 2008 & 0 & 1845 & 820 & 320 & 40 & 3025 \\
\hline
\end{tabular}

Source: CNB

We think that the drop in liquidity was caused by the overall state of Czech fixed income markets. Firstly, the swap markets are tightly connected with government bonds that were under considerable stress during autumn 2008. The Czech Ministry of Finance even suspended issues of coupon bonds from October 2008 to February 2009. The balance of payments shows that the stress was caused mainly by foreign investors selling their holdings. There was large outflow of portfolio fixed income investments that lasted from September 2008 to April 2009 and totalled CZK 47.2bn. Large part of this outflow was connected to government bonds. Secondly, the drop in liquidity was apparent also in other segments of interbanking markets. The volume of FRA contracts fell between April and October 2008 by $90 \%$. The volume of deposits declined by $10 \%$ and the share of overnight deposits on total deposits increased from $74 \%$ to $91 \%$.

\section{Swap Curve Determinants}

In this section we will focus on the determinants of key swap curve parameters in 2008 and 2009. The Czech swap curve seems to be impacted by three major factors monetary policy, euro interest rates and risk premiums.

\subsection{Monetary policy}

Swap rates are derivates of money markets rates and money market rates play a key role in the monetary transmission mechanism of the central bank as they are anchored by policy rates like two week repo rate in the Czech Republic. The usually reaction of the market is that lower policy rates reduce key money market rates and to some extend also longer maturities as long-term forwards are more stable. The natural reaction of the swap curve is to decline and to get steeper. The following graph shows that the reaction of the swap curve was not typical during the crises period. 
Figure 9

Two Week Repo and Key Swap Curve Parameters

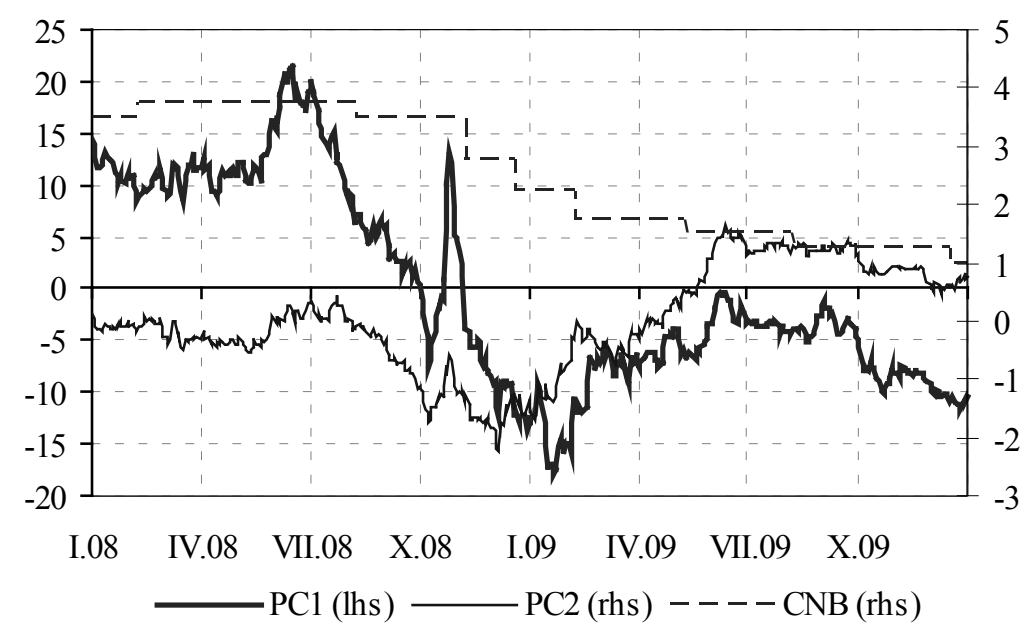

Source: Author's estimates, CNB

The swap curve increased in the middle of 2008 following the final hike of ECB. The first rate cut of CNB from August 8 was accompanied with a declining swap curve as shown by the level component (PC1). The trend was interrupted by the Lehman Brothers failure and the disintegration of the global financial system. On the other hand, the swap curve flattened till the end of 2008 despite the interest rate reduction of 150 bp from $3.75 \%$ to $2.25 \%$ in December 2008 . The swap curve showed more typical steeping especially in $1 \mathrm{H} 2009$, when CNB continued to reduce rates and other factors turned more favourable - risk premiums started to decline (see following section), the currency stabilized (the CZK depreciated by around $25 \%$ during the crises and low was reached in February 2009). The decline and flattening of swap curve in $2 \mathrm{H} 2009$ was caused by the combination of further CNB interest rate reduction and declining risk premiums.

\subsection{Euro rates}

The Czech interest rates are closely connected to euro interest rates. There are deep fundamental reasons. Firstly, the Czech economy is a small open economy and its business cycle depends mainly on the development of its main trading partners and those are the EMU countries. Secondly, there is a high probability the Czech Republic will join the euro area in the future, although is not a question of next two or three years. Thirdly, the financial markets are deeply interconnected by free capital movement and large and more liquid markets usually lead a smaller one. The comparison of level components of Czech and Euro swap curve is in Figure 10. 
Figure 10

Level Component of Czech and Euro Swap Curve

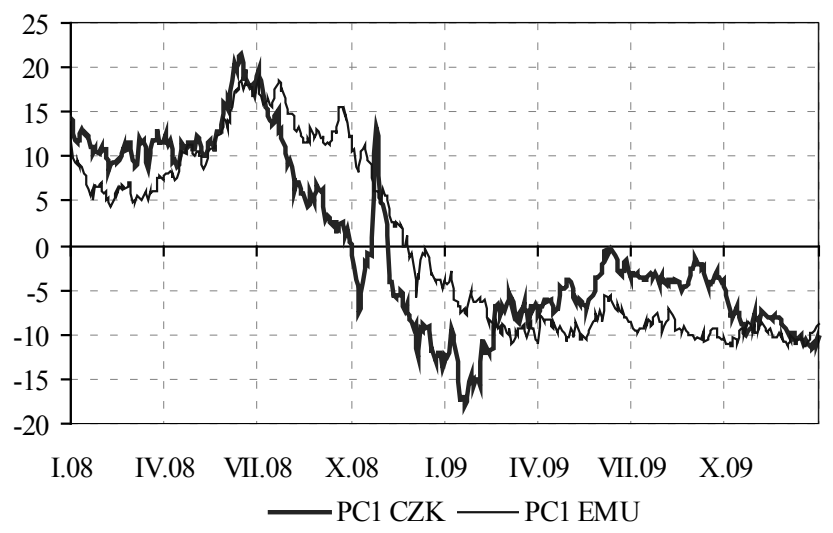

Source: Author's estimates

It is clear that that Czech swap curve was more volatile during the crises period than the euro swap curve. The exception is $1 \mathrm{H} 2009$, when ECB reacted to the late cycle inflation despite opposing signals from the financial markets and real economy. The relative low stability of the Czech swap curve during the crises period may be attributed to lower liquidity of the Czech market and to larger set of relevant determinants that we described in other sections. Czech rates tend to overact what was typical for other peripheral assets or markets.

\section{Euro/Czech spreads}

The spreads are functions of swap interest rates and share almost identical variance structure. We can again identify components tracking level of spreads, slope and curvature of spreads. The first (level) component dominates with $95.2 \%$ variability explained. The second (slope) explains $4.4 \%$ of variability and other components are almost negligible.

Figure 11

\section{Component Structure of Euro/Czech Spreads}

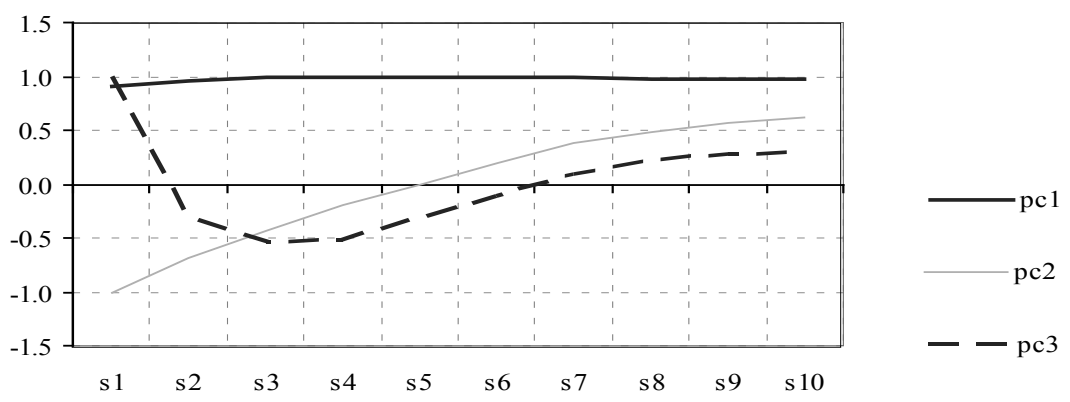

Source: Author's estimates 
The crises had a big impact on spreads between euro and Czech swap rates. The Czech interest rates were lower in the months the preceded the financial crises and the level component was getting increasingly negative. This was mainly about different policy of central banks and the differences were thus higher for shorter maturities. During the autumn 2008 Czech swap rates clearly underperformed the EMU swap rates and the adjustment was highly nonlinear and abrupt. This is typical for a crises period risk premiums widen and non-core markets tend to underperform liquid assets with "safe heaven" status. The second component shows remarkable flattening of spread curve during the crises period. Shorter maturities were more impacted than longer maturities. The spreads started to steepen again after the crises calmed down and CNB followed ECB in rates cuts, but spreads for shorter maturities remained relatively high in comparison to pre-crisis period.

Figure 12

Key Components during the Crises Period

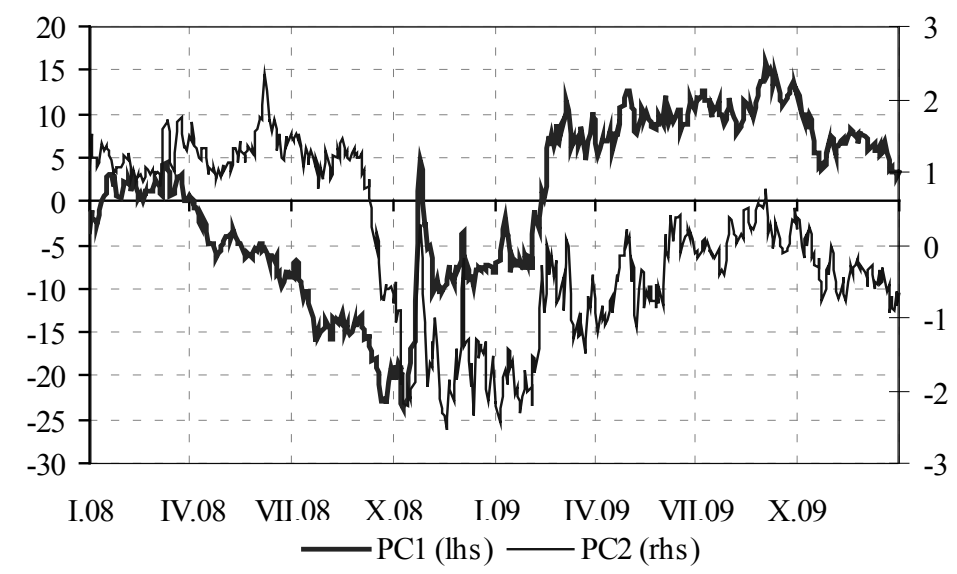

Source: Author's estimates

Alternative way to represent the distance between both curves is to use Mahalanobis metric and the mean spread for every period. The mean has the disadvantage that it may be biased in the presence of negative and positive average spreads during the period. Both indicators give similar signal with the exemption of 3Q 2008, where average spreads reached local peak, but Mahalanobis shows that the differences were smaller than in 2Q 2008. The 3Q 2008 was an period of extremes - as at the beginning the ECB pushed euro rates up in a fight against inflation, but in September the financial crises started with the collapse of Lehman Brothers and the relation between both curves started to reverse. 
Figure 13

\section{Euro/Czech Swap Curve Distance}

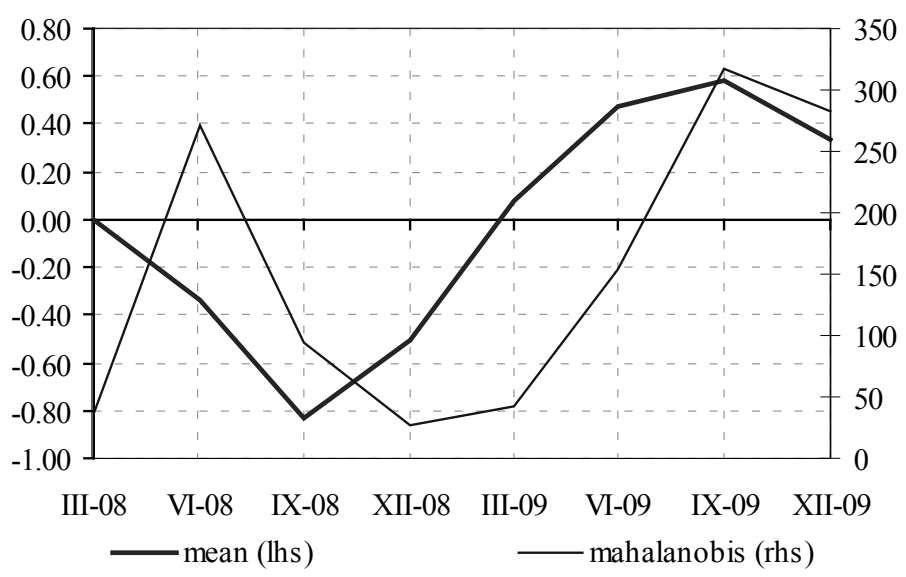

Source: Author's estimates

Both curves were relatively "similar" during the crises period in 4Q 2008 and 1Q 2009. This means that Czech swap curve was relatively rising from below euro levels and spreads were around zero during this period before they turned decisively positive in the rest of 2009. In 4Q 2009 the spreads between both swap curves started to decline again.

\subsection{Risk premiums}

Risk premiums in swap markets are usually very low and swap rates may be considered as "risk free" rates. Nevertheless, the 2008/2009 crises period showed that the variation of risk premiums may have significant impact on the swap curve. We may even say that the variation of risk premiums was among deciding factors especially for the slope of the swap curve.

The key link between the swap curve and financial crises was the money market. The link between policy rates (two week repo) and key money market rates has become weaker during the crises period. Although the CNB started to cut interest rates already in August 2008 the 3M Pribor continued to increase until it peaked in March 2009 almost $2.8 \mathrm{pp}$ above to policy rate. In normal times the $3 \mathrm{M}$ Pribor would be similar to two week policy rate or even lower as it would reflect expectations of further rate cuts. Money market rates had a significant impact on swap rates with short maturity as market expected the shock to be temporary and conditions in the money markets to normalize. The outcome was unusual behaviour of the swap curve that flattened during $2 \mathrm{H} 2008$ despite lower policy rates. The swap curve slope returned to its usual behaviour in 2009 with the exemption of a brief flattening in February/March 2009. 
Figure 14

\section{Swap Curve Slope and Key Money Market Rates}

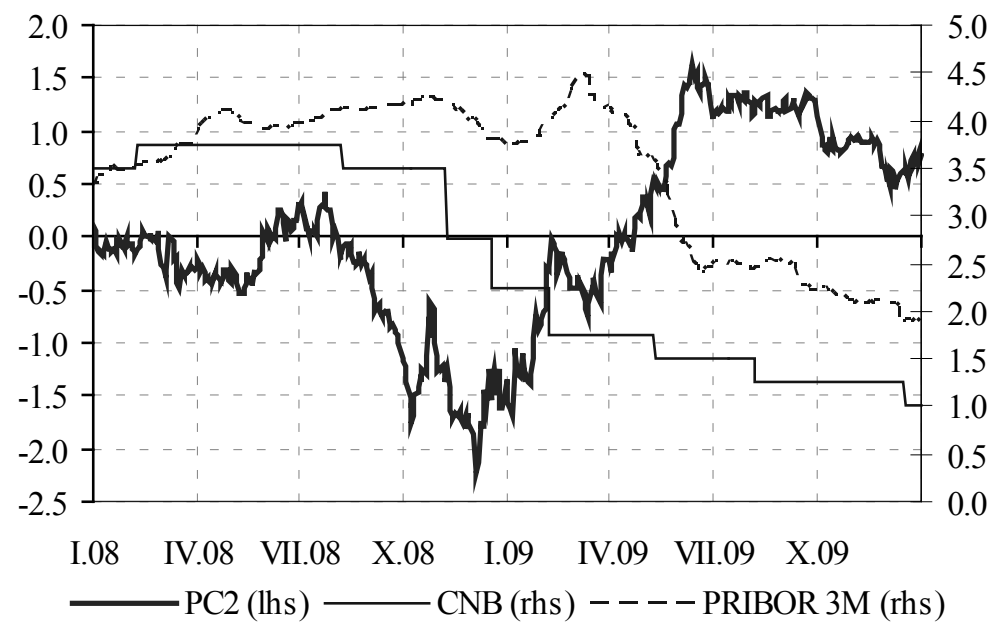

Source: Author's estimates, CNB

\subsection{Money markets during the crises period}

The stress in the funding markets was a global characteristic of the 2008/2009 financial markets. The usually interpretation of the development is based on the decomposition of interbanking rates into three components - the "risk free" rate, credit and liquidity premium. The premiums became dominant in all major markets (IMF 2008), but there is no general agreement on the importance of both premiums.

The decisive impact of credit premium is supported by all authors. The money market rates may be understood as marginal funding interest rates of banks and they are in essence unsecured short term loans. Several studies have confirmed (Taylor, 2008) that the risk premiums were correlated with the credit risks associated with the banks measured by CDS contracts. According to the CNB (CNB, 2009) the credit risk was also dominant in the Czech interbanking market. This is roughly confirmed by the development of average CDS for Pribor banks and key money market rates as shown in the following graph. The CDS for Pribor reference banks increased during 2008 until they peaked in the Spring 2009 and the same seems to be the case also for risk premiums in interbanking market. It would be more appropriate to use a spread between Pribor 3M and some "risk free" short term interest, but liquidit benchmarks like OIS swaps are not available for the Czech market. 
Figure 15

Average CDS for PRIBOR Reference Banks and Key Money Market Rates

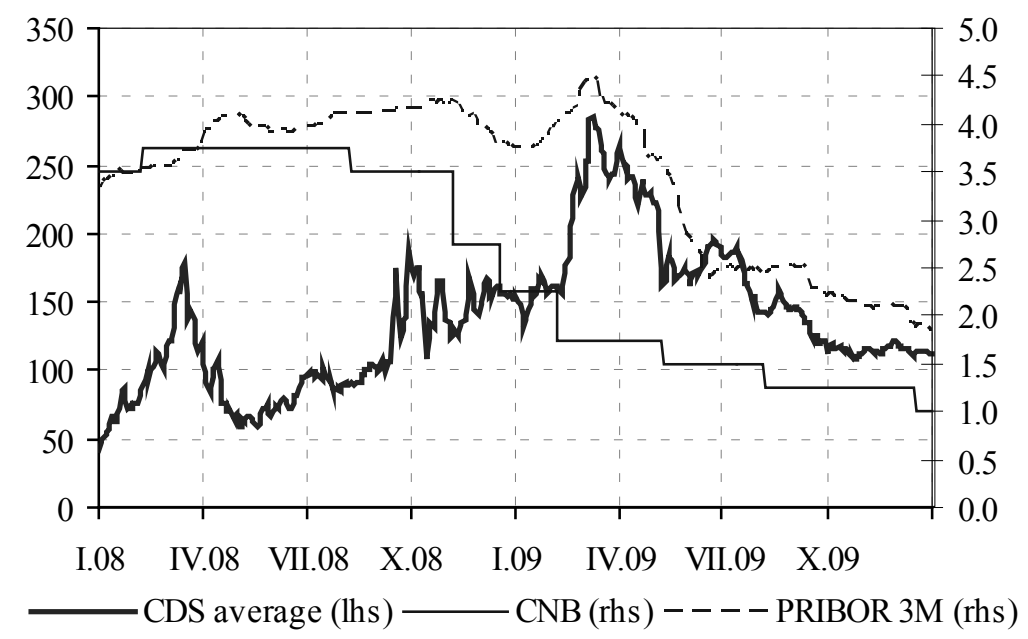

Source: Author's estimates, Bloomberg

The composition of the reference basket may explain part of the high correlation between various interbank markets. As shown in the following table the Pribor panel includes many of key European and American banks and the large Czech banks are also owned by foreign international banks. We used the CDS on Pribor banks in our calculation of an average CDS for PRIBOR reference banks. For large Czech banks where CDS are not available we used the CDS for their parent bank.

Table 3

List of Reference Banks for the Calculation of Reference Interest Rate

\begin{tabular}{|l|l|}
\hline Reference bank & CDS \\
\hline Crédit Agricole Bank S.A. Prague & yes \\
\hline Citibank Europe plc & yes \\
\hline Česká spořitelna, a. s. & Erste Group \\
\hline Československá obchodní banka, a. s. & KBC \\
\hline Deutsche Bank AG Filiale Prag & yes \\
\hline ING Bank N. V. & yes \\
\hline Komerční banka, a. s. & Societe Generale \\
\hline LBBW Bank CZ a. s. & no \\
\hline Raiffeisenbank a. s. & yes \\
\hline The Royal Bank of Scotland N.V. & yes \\
\hline UniCredit Bank Czech Republic, a. s. & yes \\
\hline
\end{tabular}

Source: CNB 
The liquidity risk may have also significant impact, although the evidence is less conclusive (ECB, 2008; Taylor, 2008). In reality the liquidity risk is indistinguishable from the credit risk and researches face a difficult identification problem. The Czech National Bank supports $(\mathrm{CNB}, 2009)$ the view that the liquidity in the Czech money market was not relevant. The main reason is the different position of the Czech banking sector. The CNB withdraws liquidity by reverse repos, but it is more common that central bank provide liquidity. We agree that the liquidity was less an issue in the Czech context, but we think that further investigation is required. Firstly, a banking sector in liquidity surplus may include also banks that may face high liquidity risk due to their composition of assets and liabilities. Secondly, ex post liquidity is not the same as $e x$ ante liquidity. The banks may consider higher risk of a bank run in the future and this may motivate them to hoard liquidity. It is important to mention that the key element of the financial crises may be an updated version of a bank run (see Gordon, 2009) that impacted wholesale market in advance countries.

\section{Conclusion}

Our analysis confirmed that the Czech swap curve may be represented by level, slope and curvature components. These parameters were stable during the crises period that culminated in the autumn 2008. The basic swap curve characteristics are showing most abnormal behaviour during periods of relative calm development, when the swap curve barely changes. From practical point of view such periods are less important and the reliance on standard yield curve parameters remains a useful simplification for the Czech swap market. We found that the multivariate structure of bid/ask spreads may be also decomposed into components that represent level, slope and curvature. The spreads seemed to lag other variables and they continued to increase till 3Q 2009. The financial crises also disturbed standard sensitivity of key swap curve parameters to CNB's monetary policy. We showed that this was caused mainly by elevated risk premiums in the money market. The financial crises reversed the spreads between Euro and Czech swap curve. Before the Lehman Brothers turmoil the Czech swap rates were on average lower due to lower policy rates, but after the crises CNB reduced its interest rates slower than ECB and also risk premiums in the Czech market tended to decline slower than in the euro market. Although swap rates may be considered as "risk free" interest rates, the financial crises had a large impact on liquidity in the swap market, but it was less pronounced than in other segments of fixed income markets.

\section{References}

Clarida, R. (2001), "The Empirics of Monetary Policy in Open Economies." NBER Working Paper 8603.

Cícha, M. (2010), "Czech Yield Curve." Research Centre for Competiveness of the Czech Economy, Working Paper No. 11/2010.

Czech National Bank (2009), Financial Stability Report 2008/2009, Prague, CNB.

Czech National Bank (2010), Financial Stability Report 2009/2010, Prague, CNB.

Dieudonne, M. (2004), Principal Component Analysis. Düsseldorf: WestLb Research. 
European Central Bank (2008), Financial Stability Review - December 2008. Frankfurt: ECB.

Gorton, G. (2009), "Slapped in the Face by the Invisible Hand: Banking and the Panic 2007." Yale University, NBER Working Paper.

Hebák, P. (2005), Vícerozměrné metody 3 (Multivariate Methods 3). Praha: Informatorium.

International Monetary Fund (2008), "Stress in Bank Funding Markets and Implications for Monetary Policy." In Global Financial Stability Report - October 2008, IMF, pp.69 - 104.

Kladívko, K. (2010), "The Czech Treasury Yield Curve from 1999 to the Present." Czech Journal of Economics and Finance (Finance a úvěr), 60(4), pp. 307-335.

Martellini, L.; Priaulet, P.; Priaulet S. (2003), Fixed-income securities. London: Wiley Finance.

Málek, J. (2005), "Dynamika úrokových měr a úrokové deriváty (Interest Rate Dynamic and Derivates)." Praha: Ekopress.

Málek, J.; Radová, J.; Štěrba, F. (2007), "Konstrukce výnosové křivky pomocí vládních dluhopisů v České republice (Yield Curve Construction using Government Bonds in the Czech Republic)." Politická ekonomie 2007, Vol. 55, No. 6, pp 792-808.

Slavík, M. (2001), "Odhad časové struktury úrokových sazeb z cen domacích dluhopisů (Interest Rates Time Structure and Domestic Bond Prices)." Czech Journal of Economics and Finance (Finance a úvěr), 51: pp. 591-606.

Taylor, J.; Williams, J. (2008), "A Black Swan in the Money Market.” NBER Working Paper No. 13943.

Witzany, J. (2009), "Valuation of Convexity Related Interest Rate Derivatives." Prague Economic Papers, 2009(4), pp. 309-326. 